\title{
Evaluation of Geriatric Fractures Admitted to the Emergency Department According to Years and Seasons
}

\section{Acil Servise Başvuran Geriatrik Kırıkların Yıllara ve Mevsimlere Göre Değerlendirilmesi}

\author{
Necip Güven', @Ramazan Sami Aktaş², ๑Tülin Türközü', @Gizem Gizli², $\odot$ Abbas Tokyay', \\ Sevdegül Bilvanisi² \\ 1 Van Yüzüncü Yıl University, Faculty of Medicine Orthopedics Traumatology Department, Van, Turkey \\ 2 Van Yüzüncü Yıl University, Faculty of Medicine Department of Emergency, Van, Turkey
}

\begin{abstract}
Objective: With the rapidly increasing and diversifying elderly population of industrialized countries, the incidence of geriatric fractures is gradually increasing. The aim of this study is to evaluate the distribution of geriatric fractures according to the prevalence, age, sex, season and years.

Material and Method: Analyzes of geriatric fractures in patients aged 65 and over who were admitted to our emergency department between January 2015 and December 2020 were performed according to the most common fracture locations (hip, distal forearm, proximal humerus and ankle). The distribution of these fractures by age, gender, seasonal characteristics and years was evaluated

Results: A total of 370 cases (168 male, and 202 female patients) with an average age of $79.5 \pm 9.02$ years were included in the study. The most common fracture stypes in order of decreasing frequency were fractures of the hip $(51.7 \%)$, distal forearm (25.1\%), proximal humerus $(12.4 \%)$ and ankle $(10.8 \%)$. The incidence of distal forearm fractures was significantly higher in females than males $(p=0.001)$, but any statistically significant difference was not found between genders regarding other fractures $(p>$ 0.05 ). It was observed that the incidence of hip fractures was significantly higher in the people aged 86 years and over, while the other fractures were more frequently seen in the 65-75 age group. A seasonal feature was not observed in all fractures. The highest rate of hip fractures was seen in the year 2020. There was no difference in the distribution of other types of fractures over the years

Conclusion: It has been concluded that the incidence of geriatric fractures increases relatively in conditions of social isolation and does not show seasonal characteristics in our region. We are of the opinion that a good management strategy should be determined characterized with both the isolation of these patients and their early treatment and discharge in disasters as pandemics, and the incidence of geriatric fractures that can be mortal with advancing age should be very well known.
\end{abstract}

Keywords: Geriatric fractures, hip, distal forearm, weather, elderly
Öz

Amaç: Günümüzde sanayileşmiş ülkelerin hızla artan ve çeşitlenen yaşlı nüfusa sahip olması ile beraber bu kırıkların görülme sıklığı giderek artmaktadır. Bu çalışmanın amacı geriatrik kırkların görülme sıklığı, yaş, cinsiyet, mevsim ve yıllara göre dağıımını değerlendirmektir.

Gereç ve Yöntem: Ocak 2015- Aralık 2020 yılları arasında acil servisimize başvuran 65 yaş ve üstü geriatrik kııklı hastaların en sık görülen kırık lokalizasyonuna göre (kalça, distal önkol, proksimal humerus ve ayakbileği kırıkları) analizleri yapıldı. Bu kırıklar yaş, cinsiyet, mevsimsel özellik ve yıllara göre dağılımları değerlendirildi.

Bulgular: Çalışmaya alınan 370 hastanın 168 tanesi erkek 202 tanesi kadın olup yaş ortalaması 79,5 $\pm 9,02$ idi. En sık görülen kırık tiplerinin görülme sıklığına göre sırasıyla; kalça $(\% 51,7)$, distal önkol(\%25,1), proksimal humerus $(\% 12,4)$ ve ayak bileği kırığı $(\% 10,8)$ olduğu görüldü. Distal önkol kırıklarının kadınlarda erkeklere oranla istatistiksel olarak anlamlı bir şekilde yüksek olduğu $(p=0,001)$, ancak diğer kırıklarda cinsiyetler arasında istatistiksel olarak fark görülmemiştir ( $p>0,05)$. Kalça kırıklarının 86 yaş ve üzeri gurubunda anlamlı olarak yüksek olduğu, diğer kırıkların ise 65-75 yaş aralığında daha yüksek olduğu görülmüştür. Tüm kırıklarda mevsimsel bir özellik görülmemiştir. Kalça kırıklarının 2020 yılında en yüksek oranda görülmüştür. Diğer kırıklarda ise yıllar arasında kırık dağı̆ımı açııından fark görülmemiştir.

Sonuç: Geriatrik kırıkların sosyal izalosyonda rölatif olarak arttığı ve yöremizde mevsimsel özellik göstermediği sonucuna varılmıştır. Yaşın ilerlemesi ile mortal olabilecek geriatrik kırıkların insidansının iyi bilinmesi ve pandemi gibi durumlarda bu hastaların hem izolasyonu hem de erken tedavi edilip taburcu edilmesi ile birlikte iyi bir yönetim stratejisi belirlenmesi gerektiğ kanaatindeyiz.

Anahtar Kelimeler: Geriatrik kırıklar, kalça, distal önkol, hava durumu, yaşlılar

Corresponding (illetişim): Necip Güven, Van Yuzuncu Yıl University, Faculty of Medicine Orthopedics Traumatology Department, Van, Turkey E-mail (E-posta): ortodr.nguven@gmail.com 


\section{INTRODUCTION}

Geriatric fractures emerge as an important public health problem and are among the frequent reasons for admissions to the emergency services. ${ }^{[1]}$ These fractures mostly occur in osteoporotic individuals as a result of simple falls during daily activities. Along with poor vision and decreased reflexes, many causative factors as well as the presence of osteoporosis predispose to the development of fractures. Today, with the rapidly increasing elderly population of industrialized countries, an increase in the incidence of these fractures is anticipated. ${ }^{[2,3]}$ It has been also reported that the incidence of these fractures show a seasonal change. ${ }^{[4]}$ Especially older age, gender, the presence of additional diseases, and the type of fracture can affect daily living activities and quality of life of the geriatric patients. ${ }^{[5]}$

It is very important to carry out studies on the incidence of geriatric fractures and to update information on this issue. Considering the health expenditures and intensive care burden, it can be thought that this burden can be partially reduced by plans to be performed at aiming at prevention of geriatric fractures. The aim of this study is to examine the frequency of fractures in geriatric patients admitted to our center and the distribution of these fractures by age, sex, season and years. Another feature of our study is that patients who applied since the first implementation of social restrictions during the pandemic were included in the evaluation.

\section{MATERIAL AND METHOD}

The data related to the extremity fractures of patients aged 65 and over, who were admitted to the emergency service between January 2015 and December 2020 and consulted to the orthopedics-traumatology clinic, were scanned from the automation records of our hospital using the International Classification of Diseases-10 (ICD-10) system. These fractures were classified according to their anatomical location. Among 563 patients diagnosed with fractures, 370 cases that had four most common types of fractures (hip, distal forearm, proximal humerus and ankle) were evaluated. The distribution of these fractures by age, sex, season and years was evaluated. The patients were divided into 3 groups in terms of age distribution as 65-75, 76-85 and 86 years and above. Patients with missing data in the automation system and cases that were not evaluated by the orthopedic clinic, and patients with pathological fractures and multiple fractures were excluded from the study.

The study was carried out with the permission of Van Yüzüncü Yıl University Non-Invasive Clinical Research Ethics Committee (Permission granted: 16.10.2020, Decision no: 2020/07-02).

\section{Statistical analysis}

The sample size of this study which was carried out for the analysis of common fractures in geriatric patients, was determined for each variable by considering the minimum statistical power of the test as $80 \%$ with type 1 error of $5 \%$. Categorical variables in the study were expressed as numbers and percentages. Chi-square test was used to determine the relationship between "fracture type groups" and categorical variables. In the calculations, the statistical significance level was taken as (a) $5 \%$ and the SPSS (IBM SPSS for Windows, ver.24) statistics package program was used for analysis.

\section{RESULTS}

A total of 370 cases (168 male, and 202 female patients) with an average age of $79.5 \pm 9.02$ were included in the study. The most common types of fractures in order of decreasing frequency were fractures of the hip (51.7\%), distal forearm (25.1\%), proximal humerus (12.4\%) and ankle (10.8\%). Demographic data of our patients are given in Tables 1 and $\mathbf{2}$.

Table 1 is examined, it is seen that the rates of distal forearm fractures are statistically significantly higher in women compared to men, but there is no statistically significant difference between genders in terms of other fractures.

Table $\mathbf{2}$ is examined, it is seen that the rates of hip fractures are statistically significantly higher in the age group of $\geq 86$ years, while the other fractures are seen at a significantly higher in the 65-75 age group.

Table $\mathbf{3}$ is examined any seasonal difference is not seen in terms of all fractures.

As seen in Table 4, the highest rate of geriatric hip fractures was seen in 2020, while any difference is not noted in the distribution of other fracture types over the years.

\begin{tabular}{|c|c|c|c|c|c|}
\hline & \multicolumn{2}{|c|}{ Male } & \multicolumn{2}{|c|}{ Female } & \multirow{2}{*}{ *p. } \\
\hline & $\mathbf{n}$ & $\%$ & $\mathbf{n}$ & $\%$ & \\
\hline Hip & 106 & 55.5 & 85 & 44.5 & 0.129 \\
\hline Distal forearm & 21 & 22.6 & 72 & 77.4 & 0.001 \\
\hline Proximal humerus & 21 & 45.7 & 25 & 54.3 & 0.555 \\
\hline Ankle & 20 & 50.0 & 20 & 50.0 & 1.00 \\
\hline
\end{tabular}

\begin{tabular}{|c|c|c|c|c|c|c|c|}
\hline & \multicolumn{2}{|c|}{$65-75$ years } & \multicolumn{2}{|c|}{$76-85$ years } & \multicolumn{2}{|c|}{$86+$ years } & \multirow{2}{*}{${ }^{*} \mathbf{p}$} \\
\hline & $\mathbf{N}$ & $\%$ & $\mathbf{N}$ & $\%$ & $\mathbf{N}$ & $\%$ & \\
\hline Hip & 45 & 23.6 & 70 & 36.6 & 76 & 39.8 & 0.014 \\
\hline Distal forearm & 52 & 55.9 & 26 & 28.0 & 15 & 16.1 & 0.001 \\
\hline Proximal humerus & 24 & 52.2 & 12 & 26.1 & 10 & 21.7 & 0.024 \\
\hline Ankle & 31 & 77.5 & 7 & 17.5 & 2 & 5.0 & 0.001 \\
\hline
\end{tabular}

* Levels of significance according to one sample chi-square test

\begin{tabular}{|c|c|c|c|c|c|c|c|c|c|}
\hline & \multicolumn{2}{|c|}{ Winter } & \multicolumn{2}{|c|}{ Spring } & \multicolumn{2}{|c|}{ Summer } & \multicolumn{2}{|c|}{ Autumn } & \multirow{2}{*}{ *p. } \\
\hline & $\mathbf{N}$ & $\%$ & $\mathbf{N}$ & $\%$ & $\mathbf{N}$ & $\%$ & $\mathbf{N}$ & $\%$ & \\
\hline Hip & 58 & 30.4 & 48 & 25.1 & 48 & 25.1 & 37 & 19.4 & 0.202 \\
\hline Distal forearm & 26 & 28.0 & 22 & 23.7 & 30 & 32.3 & 15 & 16.1 & 0.152 \\
\hline Proximal humerus & 7 & 15.2 & 8 & 17.4 & 18 & 39.1 & 13 & 28.3 & 0.082 \\
\hline Ankle & 10 & 25.0 & 14 & 35.0 & 10 & 25.0 & 6 & 15.0 & 0.362 \\
\hline
\end{tabular}




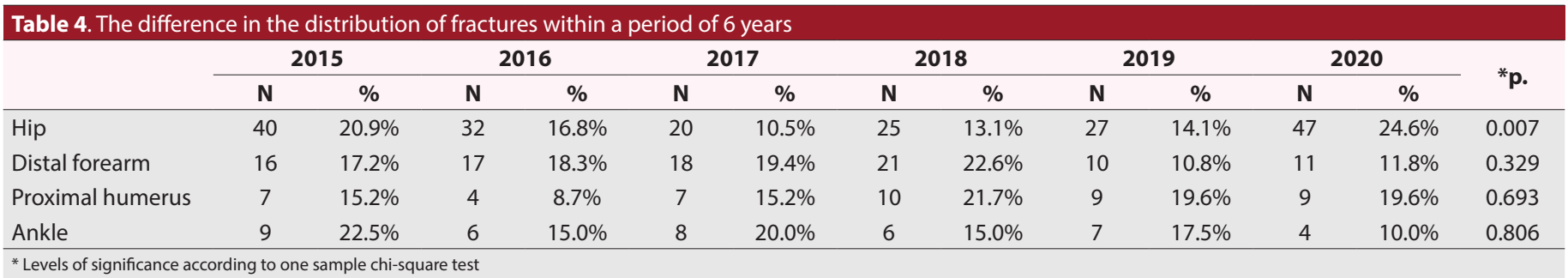

\section{DISCUSSION}

In this study, in which the distribution of geriatric fractures by age, sex, localization, seasonal characteristics and years was investigated hip fractures ranked on top, followed by distal forearm, proximal humerus and ankle fractures in decreasing order of frequency. It was observed that these fractures were more common in women and also distal forearm fractures were seen at significantly higher rate in women than men.

Considering the seasonal variation of the incidence rates of fractures, any significant change was not detected in our region. The distribution of fractures by years revealed that the incidence of hip fractures increased compared to previous years with the pandemic restrictions in 2020, while incidence of fractures in other localizations did not vary by years.

Similar to our study, geriatric fractures have attracted considerable attention in the literature and many studies have been conducted in this area. ${ }^{[1,3,6]}$ Geriartric fractures, which constitute a serious public health problem, have been investigated and many preventive methods have been defined due to their relationship with osteoporosis. In these studies, especially effects of osteoporosis on the incidence, mortality and health expenditures of hip fractures were highlighted. ${ }^{[7,8]}$ In our study, fracture localization, age-gender distribution, and the long-lasting winter season in our region on fractures were examined in more detail rather than the relationship between these fractures and osteoporosis.

According to the location of the fractures, hip fractures were seen more frequently, especially in the patient population aged 86 years and over $(P=0.014)$. When we reviewed the relevant literature similar to our study, a large-scale national study conducted in Ukraine indicated that, the incidence of hip fractures at the age of 80 and over was 10 times higher than the lower geriatric age groups, indicating a statistically significant intergroup difference. It has been also reported that this result is related to increases both in the incidence of osteoporosis and the population of this age group. ${ }^{\left[{ }^{[9]}\right.}$ In a study conducted on geriatric hip fractures, Lewiecki EM et al. ${ }^{[10]}$ reported that the hip fracture rates were higher than predicted and this rate increased significantly, especially at the age of 80 and over. They also recommended conduction of further studies to evaluate all factors contributing to this important change in hip fracture rates and to develop strategies for the treatment of osteoporosis.

Distal forearm fracture is another common fracture type seen in geriatric patients. We observed that these fractures were statistically significantly more often seen in women than men. In a study conducted in 2020, Zakroyeva et al. ${ }^{[1]}$ reported that distal forearm fractures were more common in women than in men (female / male ratio $=3.5$ ). In their study, the incidence of fractures in women increased at the age of 69 , and then decreased with age. In men, its incidence decreased with increasing age. Gül et al. ${ }^{[12]}$ reported that women had more often suffered from distal forearm fractures than men. In a large -scale case series conducted on patients with geriatric osteoporosis, distal forearm fractures were reported to be more frequently seen in women than men. ${ }^{[13]}$ In our study, it was found that these fractures were more common in the 65-75 age group, and forearm fractures decreased in both genders with increasing age. It is thought that increasing osteoporosis in postmenopausal women may be related to this result.

It was observed that the rates of proximal humerus and ankle fractures we also encountered in our study, were close to each other. Although these fracture types have not attracted much attention as hip and distal forearm fractures in the literature, it should be kept in mind that the localization of these two fractures is important, and that especially long-term immobilization of patients with ankle fractures will bring along fatal risks such as embolism, etc. In a study conducted on ankle fractures of elderly populations, it was emphasized that these patients constituted a heterogeneous group of cases with diabetes, neuropathy, osteopenia which created difficulties in treatment. ${ }^{[14]}$ In our study, these fractures were more frequently seen in the 65-75 age group and the incidence of ankle fractures decreased in both genders with aging.

In present study, the seasonal distribution of geriatric fractures also did not differ among types of fractures. In a previous study; it was reported that hip fractures were seen with a higher rate in the winter months. ${ }^{[15]}$ Some studies have indicated that falls due to slippery ground covered with snow and ice may play an important role in the incidence rates of seasonal fractures. ${ }^{[16]}$ In another study, it was reported that hip fractures in women over the age of 50 did not convey seasonal characteristics, and the incidence rates of hip and wrist fractures were higher in men in winter. ${ }^{[17]}$ It has been indicated that incidence rates of the hip, distal forearm, humerus and ankle fractures increase in the winter in elderly individuals, but hip fractures show less seasonality than other fractures, and these fractures mostly develop as a result of domestic falls. ${ }^{[4]}$ The incidence of fractures of the proximal humerus increases with age and have been observed more frequently in the winter months. ${ }^{[18]}$ 
In another study, it was reported that there was no statistically significant relationship between the incidence of geriatric fractures and weather conditions (seasonal characteristics). ${ }^{[19]}$

Considering the distribution of fractures by years in our study, it was seen that the fractures other than hip fractures did not show any statistical change over the years. It was determined that hip fractures were most common in 2020, when social isolation measures were applied. Different studies have been reported in the literature on variations inthe incidence rates of geriatric fractures over the years. In a national data-based study published in 2017; declining trends in the incidence of lower body (hip, pelvic and lower spine) and wrist fractures have been suggested over the past 11 years (2004-2014). In another study, it was reported that in 2011720,000 cases with geriatric fractures were seen in Germany and that its rates will increase by $28 \%$ by $2030 .{ }^{[20]}$

Another common problematic issue of geriatric fractures is related to comparative incidence rates of indoor and outdoor fractures. Geriatric distal forearm fractures tend to occur in relatively active individuals due to slipping during strolling outside, whereas hip fractures usually occur indoors in more fragile elderly patients. ${ }^{[21]}$ It has been reported that indoor fractures were seen more frequently in geriatric patients subjected to domestic restrictions during the pandemic period, and especially the number of cases with hip fractures increased in hospital admissions, It has been indicated that inadequate support received by these individuals from relatives and caregivers because of the social isolation policy may have been presumably held responsible for increasing rates of hip fractures. ${ }^{[22]}$ In our study, which analyzed fractures seen within a period of 6 years extending from 2015 to 2020 (incl.), similarities in annual rates of geriatric fractures were observed, but statistically significantly greater number of hip fractures were found in the period when social restrictions were imposed.

The most important limitation of this study is that it was conducted in a single center and with a relatively small number of patients. Retrospective design of our study was its another limitation, thus the relationship between fractures and Bone Mineral Density (BMD) and Body Mass Index (BMI) could not be evaluated.

\section{CONCLUSION}

In this study, it was concluded that geriatric fractures increase relatively in social isolation and do not show seasonal variations in our region. Another important result derived from our study is that, while the distal forearm, proximal humerus and ankle fractures caused by simple falls in partially more active geriatric individuals aged 65-75 years are associated with lower mortality rates, hip fractures are more often indoor fractures with higher mortality rates in older patients. With increasing age a good management strategy can be determined based on isolation, early treatment and discharge of these patients in pandemic periods and being very knowledgeable about the incidence of potentially mortal geriatric fractures.

\section{ETHICAL DECLARATIONS}

Ethics Committee Approval: The study was carried out with the permission of Van Yüzüncü Yıl University Non-Invasive Clinical Research Ethics Committee (Permission granted: 16.10.2020, Decision no: 2020/07-02).

Informed Consent: Because the study was designed retrospectively, no written informed consent form was obtained from patients.

Referee Evaluation Process: Externally peer-reviewed.

Conflict of Interest Statement: The author(s) declared no potential conflicts of interest with respect to the research, authorship, and/or publication of this article.

Financial Disclosure: The authors declared that this study has received no financial support.

Author Contributions: All of the authors declare that they have all participated in the design, execution, and analysis of the paper, and that they have approved the final version.

\section{REFERENCES}

1. Baidwan NK, Naranje SM. Epidemiology and recent trends of geriatric fractures presenting to the emergency department for United States population from year 2004-2014. Public Health. 2017;142:64-9.

2. Engelman M, Canudas-Romo V, Agree EM. The implications of increased survivorship for mortality variation in aging populations. Popul Dev Rev 2010;36:511e39.

3. Bonne S, Schuerer DJ. Trauma in the older adult: epidemiology and evolving geriatric trauma principles. Clin Geriatr Med. 2013;29(1):137-50.

4. Bischoff-Ferrari HA, Orav JE, Barrett JA, Baron JA. Effect of seasonality and weather on fracture risk in individuals 65 years and older. Osteoporos Int. 2007;18(9):1225-33.

5. Roth T, Kammerlander C, Gosch M, Luger TJ, Blauth M. Outcome in geriatric fracture patients and how it can be improved. Osteoporos Int 2010;21(Suppl 4):S615-9.

6. Johnell O, Kanis J. Epidemiology of osteoporotic fractures. Osteoporos Int. 2005; 16:S3-7.

7. Kanters TA, van de Ree CLP, de Jongh MAC, Gosens T, Hakkaart-van Roijen L. Burden of illness of hip fractures in elderly Dutch patients. Arch Osteoporos. 2020;15(1):11.

8. Borgström F, Karlsson L, Ortsäter G, et al. International Osteoporosis Foundation. Fragility fractures in Europe: burden, management and opportunities. Arch Osteoporos. 2020;15(1):59.

9. Povoroznyuk VV, Grygorieva NV, Kanis JA, et al. Epidemiology of Hip Fractures in Two Regions of Ukraine. J Osteoporos. 2018;2018:7182873.

10. Lewiecki EM, Wright NC, Curtis JR, et al. Hip fracture trends in the United States, 2002 to 2015. Osteoporos Int. 2018;29(3):717-722.

11. Zakroyeva A, Lesnyak O, Cazac V, et al. Epidemiology of osteoporotic fracture in Moldova and development of a country-specific FRAX model. Arch Osteoporos. 2020;15(1):13.

12. Gül D, Akpancar S. Fractures in Geriatric Cases. Geriatrik Bilimler Derg 2019;2:14-9.

13. Johnell O, Kanis JA. An estimate of the worldwide prevalence and disability associated with osteoporotic fractures. Osteoporos Int. 2006;17:1726e33.

14. Hsu RY, Lee Y, Hayda R, DiGiovanni CW, Mor V, Bariteau JT. Morbidity and Mortality Associated with Geriatric Ankle Fractures: A Medicare Part A Claims Database Analysis. J Bone Joint Surg Am. 2015;97(21):1748-55.

15. Serra JA, Garrido G, Vidán M, Marañón E, Brañas F, Ortiz J. Epidemiología de la fractura de cadera en ancianos en España [Epidemiology of hip fractures in the elderly in Spain]. An Med Interna. 2002;19(8):389-95.

16. Bulajic-Kopjar M. Seasonal variations in incidence of fractures among elderly people. Inj Prev. 2000;6(1):16-9. 
17. Johnson NA, Stirling E, Alexander M, Dias JJ. The relationship between temperature and hip and wrist fracture incidence. Ann R Coll Surg Engl. 2020;102(5):348-54.

18. Launonen AP, Lepola V, Saranko A, Flinkkilä T, Laitinen $M$, Mattila VM. Epidemiology of proximal humerus fractures. Arch Osteoporos. 2015;10:209.

19. Burget F, Foltán O, Kraus J, Kudrna K, Novák M, Ulrych J. Vliv počasí na výskyt zlomenin ve stárí [Influence of the Weather on the Incidence of Fractures in the Elderly]. Acta Chir Orthop Traumatol Cech. 2016;83(4):26973.

20. Ström O, Borgström F, Kanis JA, et al. Osteoporosis: burden, health care provision and opportunities in the EU: a report prepared in collaboration with the international osteoporosis foundation (IOF) and the European federation of pharmaceutical industry associations (EFPIA). Arch Osteoporos. 2011;6:59-155.

21. Bath PA, Morgan K. Differential risk factor profiles for indoor and outdoor falls in older people living at home in Nottingham, UK. Eur J Epidemiol. 1999;15(1):65-73.

22. Arafa M, Nesar S, Abu-Jabeh H, Jayme MOR, Kalairajah Y. COVID-19 pandemic and hip fractures: impact and lessons learned. Bone Jt Open. 2020;1(9):530-40. 